\title{
RECEPTION OF I. KANT'S LOGICO-EPISTEMOLOGICAL IDEAS IN ANALYTIC PHILOSOPHY
}

\author{
Synytsia A. S.
}

\section{INTRODUCTION}

At first glance it may seem that the I. Kant's philosophical ideas and analytic philosophy are completely different. After all, the research activity of the Keningberg thinker belongs to the Age of Enlightenment and the tradition of German idealism; it is full of the principles of metaphysical conceptualism. While the formation of analytic philosophy finally took place only in the first half of the twentieth century at the height of the popularity of neo-realist ideas and critique of metaphysics in logical positivism. Analytic thinkers were interested in the problem of language, not reason; the argumentation is based on empirical facts rather than metaphysical speculation; analysis of a specific problem, not the history of its solution. Therefore, for them, the latest developments in science were much more important than the achievements of previous thinkers. And yet, there was always a particular piety to the figure of I. Kant in analytic philosophy.

There are several facts to support this view. For example, A. Pap, who was one of the first to clearly outline the features of analytic philosophy and to promote its name, convinced that in order to understand the specifics of the analytic methodology one must turn to the legacy of I. Kant, as well as G. Leibniz, J. Locke, and D. Hume ${ }^{1}$. Eventually, half a century later, this thought became even stronger as scientists tried to investigate the history of analytic philosophy. In particular, M. Beaney begins the chronology of this philosophical tradition in 1781, when I. Kant published "Critique of Pure Reason" - "the work to which much subsequent philosophy responds"2. Another researcher S. Crichley called I. Kant “...the final great figure common to both continental and analytic traditions and also announces the parting of their ways"3. Despite the differences, they both sought the source of their own ideas in the I. Kant's legacy. But whereas in the case of Kantian

\footnotetext{
${ }^{1}$ Pap A. Semantics and Necessary Truth: An Inquiry Into the Foundations of Analytic Philosophy. New Haven: Yale University Press, 1958. P. 1-86.

${ }^{2}$ Beaney M. Chronology of Analytic Philosophy and Its Historiography. The Oxford Handbook of The History of Analytic Philosophy / M. Beaney (ed.). Oxford: Oxford University Press, 2015. P. 67.

${ }^{3}$ Critchley S. Continental Philosophy: A Very Short Introduction. Oxford: Oxford University Press, 2001. P. XI.
} 
schools in continental philosophy, such causations are justified, the reception of I. Kant's philosophy in analytic philosophy must be studied in more detail.

This issue has been investigated by many researchers - in particular R. Hanna ${ }^{4}$ proposed an original interpretation of Kantian philosophy (he analyzed cognitive semantics, theory of judgment, and the correlation between the interpretations of analyticity by I. Kant and G. Frege, R. Carnap, W. V. O. Quine); D. Reed ${ }^{5}$ proved that the views of I. Kant and G. Frege are similar in the question of the logical study of arithmetic and the analysis of concepts; T. Klaasen ${ }^{6}$ analyzed the basic ideas of "Tractatus LogicoPhilosophicus" and demonstrated that they really only develop I. Kant's reasoning; V. Kozlovskyi ${ }^{7}$ investigated the influence of the ideas of "Critique of Pure Reason" on P. F. Strawson's descriptive metaphysics; V. Tsyba ${ }^{8}$ revealed the peculiarities of I. Kant's concept of intuition, and substantially supplemented his epistemology, etc. However, at present there is not enough information about how Kant's ideas were used to develop analytic philosophy. So let's try to clarify this issue. To do that we have first to find out which of the ideas of the philosophy of the German thinker give reason to find in his writings a source of inspiration for analytic philosophizing. After that two main receptions of his ideas - critical reception and apologetic reception will be considered.

\section{Kant: critique as an analytic}

I. Kant's legacy is interesting from the standpoint of analytic philosophy, first and foremost in the methodological aspects, because it gives an opportunity to understand how to conduct philosophical research. His critical method takes the form of analytic - a consistent and scrupulous study of human cognitive abilities. He formulated the notion of analytic in the context of logic, which "... is a rational science not only in form but also in matter" . Logic as a propaedeutics of understanding is separated from the realm of empirical and psychological phenomena and deals only with objective a priori

\footnotetext{
${ }^{4}$ Hanna R. Kant and the foundations of analytic philosophy. Oxford: Clarendon, 2006. XV, 312 p.

${ }^{5}$ Reed D. The Origins of Analytic Philosophy: Kant and Frege. London; New York: Continuum, 2010. X, 203 p.

${ }^{6}$ Klaassen T. Wittgenstein as a Kantian Philosopher / 2015. URL: https://philpapers.org/ archive/KLAWAA.pdf.

7 Козловський В. Стросон і Кант: дескриптивна метафізика як концептуальна передумова аналізу “Критики чистого розуму”. Sentenciae. 2016. № 1 (XXXIV). С. 25-41.

${ }^{8}$ Циба В. Концептуальність споглядання: Селарс добудовує Кантову епістемологію. Sentenciae. 2016. № 1 (XXXIV). C. 42-60.

${ }^{9}$ In original: “...ist eine Vernunftwissenschaft nicht der bloßen Form, sondern der Materie nach" [Immanuel Kants Logik, ein Handbuch zu Vorlesungen / G.B. Jäsche (her.). Königsberg: Friedrich Nicolovius, 1800. S. 9].
} 
principles. It is divided into general logic and transcendental logic. The former deals with the necessary rules of thought, its pure forms, defines the formal criteria of truth; it is the canon of understanding and reason. The latter is aimed at explaining how our perceptions of objects emerge and how we define our intuitions in appropriate categories. Transcendental logic, unlike general logic, solves epistemological problems and analyzes empirical knowledge. Importantly, the component of both logics is analytic, which, to some extent, opposes their another part - dialectic. General logic becomes analytic when "... analyzes the entire formal business of the understanding and reason into its elements, and presents these as principles of all logical assessment of our cognition" ${ }^{\prime 10}$. It sets the criteria of truth at the formal level and explains how knowledge should be reconciled with its subject. But when general logic merely imitates objective statements and becomes a fictitious tool of knowledge unrelated to the content of knowledge, it becomes a dialectic.

For its part, transcendental analytic is the logic of truth as it "expounds the elements of the pure cognition of the understanding and the principles without which no object can be thought at all"11. This logic elevates from the cognition all thoughts that are possible by means of understanding. It is formed from the very essence of sensory perception, which defines its limits. If transcendental logic is used as a universal means of cognition, it becomes a dialectic. In such circumstances, on the contrary, it will be very important to criticize dialectical illusion and to avoid all kinds of distortions in the use of the understanding and reason.

In transcendental analytics, I. Kant distinguishes analytic of concepts and analytic of principles. He tried not to define the first of them (analytic of concepts) in terms of analysis which has traditionally been understood as the process of breaking a content of the concept into separate components. He interpreted such analytics as “... analysis of the faculty of understanding itself, in order to research the possibility of a priori concepts by seeking them only in the understanding as their birthplace and analyzing its pure use in general..."12. To his mind, categories - pure reasoning concepts that enable us to think about a subject - become elements of understanding. These categories that are represented as principles are a priori aren't deduced from empirical experience. We can conceptualize the experience by applying them. In general, the system of categories he built on the basis of the principle of

\footnotetext{
${ }^{10}$ Kant I. Critique of Pure Reason / trans. by: P. Guyer, A. W. Wood. New York: Cambridge University Press, 1998. P. 198.

${ }^{11}$ Kant I. Critique of Pure Reason. P. 199.

${ }^{12}$ Ibid. P. 202.
} 
transcendental apperception is divided into subspecies of quantity (unity, plurality, totality), quality (reality, negation, limitation), relation (inherence and subsistence, causality and dependence, community) and modality (inherence and subsistence, causality and dependence, possibility impossibility). These categories allow us to understand how the human understanding works. They exhaust its content and function as pure synthetic (not analytic) concepts that are a priori in essence. We can deduce derivative concepts (the predicables of pure reason) based on these concepts, and thus to cognize the general laws of logic and to harmonize our knowledge. Finally, I. Kant built a classification of judgments on similar principles. It proves the identity of principles for analyzing different forms of thinking.

Explaining the specifics of analytic, the German thinker called it "a canon for the power of judgment that teaches it to apply to appearances the concepts of the understanding, which contain the condition for rules $a$ priori" ${ }^{\prime 3}$. Analyzing the principles, he intended to find out how we can subordinate something to the rule, that is, to understand whether it can be applied in this case. For this purpose, such kinds of principles of pure reason as the axioms of intuitions, the anticipations of perception, the analogies of experience, and the postulates of empirical thought in general are useful.

An important place in Kantian philosophy has also the division of judgments into analytic judgments and synthetic judgments, the distinction between which he outlined as follows: "Analytic judgments (affirmative ones) are thus those in which the connection of the predicate is thought through identity, but those in which this connection is thought without identity are to be called synthetic judgments" ${ }^{\prime 14}$. In analytic judgments, the predicate is already thought in the subject, and in the synthetic ones, it is outside the subject. For example, when we claim that "All bodies are extended", a predicate of extension is already in the subject. And when we say that "All bodies are heavy", the predicate of gravity can no longer be deduced simply from the content of the concept of "body". This conclusion requires additional observations. As I. Kant argued, all mathematical judgments are synthetic. The conclusion that $7+5=12$ cannot be obtained simply by analyzing the meaning of the numbers 7 and 5. However, this judgment was not received a posteriori. Mathematical judgments are synthetic a priori judgments based on a priori intuition. It is possible to obtain similar conclusions in mathematics because there are a priori forms of intuition (space and time), through which we can structure the whole chaos of sensations.

\footnotetext{
${ }^{13}$ Ibid. P. 267-268.

${ }^{14}$ Kant I. Critique of Pure Reason. P. 141.
} 
Synthetic a priori judgments play a significant role in natural science and metaphysics. Within the former (natural science), they become the principles that explain the nature of abstractions. For example, the durability of substance can not be deduced from its content. This feature is thought out $a$ priori and then the conclusion is made that the changes taking place in the physical world do not cause changes in the amount of substance - it remains unchanged. In addition, all metaphysics consists of synthetic a priori judgments. However, we construct natural science as a rigorous science and metaphysics as a science is impossible because it contains antinomies. Such statements can be both proved and refuted by the mind. However, metaphysics is real as a natural predisposition, and it can be developed theoretically as a critique of pure reason.

It is important to emphasize that critique is an analysis for I. Kant. As a result of the analysis, not only the whole is decomposed into separate constituents - it is also important to clarify the meaning of the concept, i. e. to identify its various features. A clearer concept will be the basis for the synthesis of concepts and the formation of new knowledge. Synthesis makes our knowledge holistic and systemic. It enables us to understand what place a concept occupies in the structure of theoretical knowledge. Moreover, transcendental deduction makes it possible to identify different kinds of connections between concepts and objects. This is more significant than formal inference ${ }^{15}$.

And besides, it cannot be said that I. Kant was interested only in the relation of concepts to subjects, but not to language. Critique of the power of judgments in itself must relate to language that is a means of their expression. I. Kant put it this way in the work "Anthropology from a Pragmatic Point of View" (1798): "All language is the designation of thoughts, and, conversely, the most excellent way of expressing thoughts is by language, this greatest means to understand oneself and others. Thinking is talking to yourself..."16. $\mathrm{He}$ understood that language signs in themselves do not mean anything. However, in combination with our thoughts, they become symbols. We denote the concept by words. Thus, language becomes a condition for the possibility of subjects. We may not understand each other and distort the content of the symbols. It indicates the imperfection of the language itself. To solve this kind of difficulty in expressing the logic of thinking by the means of language, we need a theory that still needs to be created. This theory should take into

\footnotetext{
${ }^{15}$ Синиця А. С. Аналітична філософія. Львів: ЛДУФК, 2013. 304 с.

${ }^{16}$ In original: Alle Sprache ist Bezeichnung der Gedanken, und umgekehrt die vorzüglichste Art der Gedankenbezeichnung ist die durch Sprache, dieses größfced) Mittel, sich selbst und andere zu verstehen. Denken ist Reden mit sich selbst" [Kant I. Anthropologie in pragmatischer Hinsicht. Leipzig: Verlag von Felix Meiner, 1912. S. 101].
} 
account the rules of the combination of syntactic and semantic means of language, and not neglect the pragmatic context of speech, since, on the one hand, we have a grammatical relation between signs and various representations that we synthesize into concepts, and on the other hand - their interpretations in certain situations. Thus, I. Kant, developing the ideas of critical idealism, inevitably comes to the conclusion about the importance of analyzing the linguistic preconditions of mental activity, which are expressed in a number of rules governing the ways in which words are aligned with their respective concepts. And although I. Kant faintly developed this theory, its ideas were consonant with the study of the rule-following problem in analytic philosophy ${ }^{17}$.

\section{Critical reception}

L. Wittgenstein was one of those who referred to the Kantian philosophy as to a means of substantiating his own philosophical conception. However, there are many parallels in the scientific literature between I. Kant's "Critique of Pure Reason" and L. Wittgenstein's "Tractatus Logico-Philosophicus". This is due to the fact that both authors intended to find out the boundaries of human knowledge. It even gives T. Klaassen reasons to assert that "the Wittgenstein of the Tractatus was Kantian in spirit. First of all, Wittgenstein's overall conclusions seem in many ways to resemble, at least in their outward appearance, those of Kant. Second, Wittgenstein can be said to resemble Kant in his essentially transcendental outlook, in particular his transcendental conclusions about the limits of language" ${ }^{\text {18 }}$. Solving the epistemological problem of finding conditions of possibility, both philosophers certainly thought formally in a similar way, because they investigated the same subject. However, I. Kant's and L. Wittgenstein's logico-epistemological conceptions differ significantly at the substantive level. The difference between their views can be formulated as follows: I. Kant had little interest in the problems of language and mostly focused on the critique of the pure reason, but L. Wittgenstein, on the contrary, analyzed the linguistic forms of expression of thinking activity and did not investigate the boundaries of the intelligence itself.

Probably, I. Kant's neglect of language problems was due to the danger of criticizing any metaphysical studies of reason. The structures of language are of a completely different nature. It is easy to demonstrate their difference from the structure of the mental constructs expressed in them. The sentences as

${ }^{17}$ Циба В. Кантове поняття правила і проблема мови. Філософська думка. 2015. № 2. C. $50-66$.

${ }^{18}$ Klaassen T. Wittgenstein as a Kantian Philosopher / 2015. URL: https://philpapers.org/ archive/KLAWAA.pdf. 
linguistic constructions express not only narrative judgments - like analytic or synthetic ones - but also questions, commands and exclamations. Such parts of speech as prepositions, conjunctions or grammatical particle do not express concepts, but they have a significant effect on the content of information captured in logical forms. Language analysis requires a substantial revision of thinking, especially abstract thinking. Therefore, investigating the basics of language, L. Wittgenstein found an empirical criterion for evaluating the expressive capacity for reason. Like I. Kant, L. Wittgenstein in "Tractatus Logico-Philosophicus" intended to set the boundaries of our knowledge. However, it is not so important for him to find out where the boundaries of a language end, as to explain why it can be applied in a certain way. He limited knowledge to experience. This indicates the realism of his philosophical position. It is important for him in the process of critical analysis to clarify all the inaccuracies of philosophical discourse, paying particular attention to metaphysical questions - the transcendental, the sense of the world, the will, the immortality of the human soul, God. Intending to explain the specifics of metaphysical entities, I. Kant focused his analysis on the study of reason, although it would be more appropriate to begin with the investigation of language.

After all, not only Kantian motifs but also Schopenhauer and Kierkegaard ones can be found in the works of "early" Wittgenstein. However, this can be explained by the coincidence of his own philosophical position with their reflections. The thing is that L. Wittgenstein mentioned I. Kant (more precisely, even the problem posed by him) only once in "Tractatus LogicoPhilosophicus". He wrote in $\S 6.36111$ : "The Kantian problem of the right and left hand which cannot be made to cover one another already exists in the plane, and even in one-dimensional space; where the two congruent figures $a$ and $b$ cannot be made to cover one another without moving them out of this space"19. L. Wittgenstein formulated this idea in the process of explaining the specifics of natural laws and their interpretation in the context of temporalspatial relations. Knowing the latest results of physics and geometry, Wittgenstein used the notion of four-dimensional space and realized that this kind of problem could be easily solved. However, the problem of causality still remains, since there is no factual necessity for one thing to happen after another one. The necessity may only be logical but not factual, because there can always be some occasions that break the causal (as it is considered) spatiotemporal connections between things.

${ }^{19}$ Wittgenstein L. Tractatus Logico-Philosophicus / trans. by C.K. Ogden. London: Kegan Paul, Trench, Trubner \& Co., 1922. P. 86. 
L. Wittgenstein also referred to I. Kant's philosophy in "Philosophical Remarks" (1930), where he wrote in $\S 108$ : "What I said earlier about the nature of arithmetical equations and about an equation's not being replaceable by a tautology explains - I believe - what Kant means when he insists that $7+5=12$ is not an analytic proposition, but synthetic a priori" ${ }^{20}$. In this way he intended to express the questions raised by I. Kant in terms of mathematical logic and analytic philosophy. Therefore, it is no coincidence that L. Wittgenstein defined arithmetic as "grammar of numbers" 21 and determined different kinds of numbers by arithmetic rules, and calculation from the neo-realistic standpoint - by its relation to space and time.

The realism justified by L. Wittgenstein is not transcendental (as in I. Kant). It is important for the Austrian thinker to establish the relation of language to reality. I. Kant's thoughts are also interesting to him as a way to look at a problem in a slightly different aspect in order to outline his own position more clearly. That is why he once again mentioned I. Kant in 1931, writing the following: "The limit of language is shown by its being impossible to describe the fact which corresponds to (is the translation of) a sentence, without simply repeating the sentence. (This has to do with the Kantian solution of the problem of philosophy)"22 / It is important for L. Wittgenstein to demonstrate how the process of expressing fact in language is going on. To express something, we must already have appropriate concepts that can only be repeated in the formulated sentence. In a similar way takes place formulation of a true statement in the logical semantics of A. Tarski, who noted in the work "The Concept of Truth in Formalized Languages" (1935): "a true sentence is one which says that the state of affairs is so and so, and the state of affairs indeed is so and so"23. In fact, this way we only duplicated the same situation with the same linguistic means. This indicates a certain limitation of the language, because doing it differently is hardly possible.

Thus, we can conclude that I. Kant's philosophical ideas were needed by L. Wittgenstein in order to substantiate his own epistemological position. The Austrian philosopher's research method is a method of logico-linguistic analysis. He understood that going beyond language is possible only as a comprehension of the unutterable. Where I. Kant discovered the antinomies of

${ }^{20}$ Wittgenstein L. Philosophical Remarks. Chicago: The University of Chicago Press, 1980. P. 129.

${ }^{21}$ Ibid. P. 130.

${ }^{22}$ Wittgenstein L. Culture and Value / trans. by P. Winch. Chicago: The University of Chicago Press, 2006. P. 10e.

${ }^{23}$ Tarski A. The Concept of Truth in Formalized Languages / trans. by J. H. Woodger. In: Tarski A. Logic, Semantics and Metamathematics. Oxford: Oxford University Press, 1956. P. 155. 
pure reason, L. Wittgenstein proposed to remain silent because transcendental theories cannot be supported by empirical facts - they are merely metaphysical speculations that arise because we possess a developed system of linguistic means.

Like for L. Wittgenstein, for A. Pap it was important to create his own philosophical conception. He compared his ideas with the research results of previous thinkers and considered the concept of necessary truth the key to understanding the specifics of analytic epistemology. In order to define its content more clearly, A. Pap became interested in Kant's critical philosophy and, in fact, was one of the first to initiate the analytic tradition of its reading.

It is important to explain that A. Pap was influenced by the philosophical ideas of W. V. O. Quine and that is why he developed the ideas of pragmatic analysis. In this regard, analytic-synthetic distinction, which was criticized by W. V. O. Quine as one of the dogmas of empiricism, also seemed unacceptable to A. Pap. He claimed that, a clear distinction between analytic and synthetic, a priori and a posteriori, logical and factual, is determined by our numerous intuitive perceptions of the necessary connections between things. In this case, the meanings that we capture in certain language constructions are not clear and changeless. Meanings have some gradation, which means that in the concept we tend to capture some of the features more often than others. The task for analytic philosophers is to find out how concepts are formed, how some of them can be deduced from another ones, and how our intuitive perceptions influence these processes. In this regard, epistemological questions - in particular the nature of analytic truth and $a$ priori knowledge, the specificity of logical truth and logical necessity, the essence of implicit (in particular ostensive definition), the connection between analysis and synonymy, various semantic and pragmatic aspects of language are key in analytical research.

Since I. Kant has explained this kind of idea in the context of analyticsynthetic distinction, it is clear that his opinion is of interest to analytic thinkers. First of all, A. Pap proposed to pay attention to such concepts, which are indispensable for understanding Kantian philosophy, as a priori knowledge and necessity, the definition of "analytic", and synthetic a priori truths in geometry and arithmetic.

A. Pap remarked that I. Kant used negative definition of a priori knowledge (as non-empirical one). This definition does not conform to the logical rules, because it does not define the definiendum. Needless to say, in epistemology such things are permissible in order to begin the process of research. When it comes to necessity as a characteristic of judgment, this feature adds nothing to the content of the judgment, but merely clarifies the way in which one component of the judgment relates to the other (subject to 
predicate, or antecedent to consequent). However, again this point is not clarified in I. Kant. Modality (possibility or necessity) adds nothing to the content of judgment, since it contains only quantity, quality and relation. Modality concerns the value of copula and expresses our relation to thought, but not to reality. But the content of such propositions as $p$ is possible and $p$ is necessary, clearly different, so, probably, as A. Pap suggested, I. Kant had in mind certain cognitive attitudes when explaining the nature of modal judgments ${ }^{24}$.

A separate point in Kantian analyzing the concept of necessity is its relation to the law of causality. Here again, A. Pap also pointed to the ambiguity in interpreting the concept of necessity in I. Kant (after all, also in D. Hume). If we claim that "for every change there is an antecedent event which is necessarily connected with it", according to A. Pap, it is not clear what is meant: whether "for every event there is an antecedent which is necessarily followed by the event", or "for every event there is an antecedent which necessarily precedes the event" ${ }^{25}$. Such a formulation does not indicate a logical necessity that connects one event to another, and it becomes possible that the event would have been causally unrelated to the previous one.

As for the Kantian definition of analytic judgment, A. Pap found a number of misconceptions. Firstly, it is not clear what "contained" means when we say that predicate is contained in the concept of the subject in analytic judgments. How exactly should it be contained? What conditions must be met? According to A. Pap, the essence of this problem from the standpoint of contemporary semantics is to elucidate the suitable criteria for the identity of concepts (intensional identity). But even in such circumstances, which exclude the psychological elements, it still remained debatable. Secondly, the class of judgments is generally much broader than the set of judgments that have a subject-predicate form. Therefore, the set of analytic and synthetic judgments, with their subjective predicate structure, is clearly narrower than the class of true judgments. In particular, under such Kantian interpretation, the status of following judgments will be unclear: 1) analytic judgment "no triangle has four sides" (because its predicate clearly contradicts the content of the subject); 2) a synthetic judgment "there are cows", in which the predicate should be the particle "is", but this conclusion contradicts I. Kant's view on the subject-predicate structure of judgment; 3) hypothetical judgments that cannot be considered in terms of subject and predicate; 4) self-contradictory judgments that do not belong to analytic ones, which by definition are true,

${ }^{24}$ Pap A. Semantics and Necessary Truth: An Inquiry Into the Foundations of Analytic Philosophy. New Haven: Yale University Press, 1958. P. 23.

${ }^{25}$ Ibid. P. 24. 
and to synthetic ones, that by definition cannot be contradictory. In addition, investigating synthetic a priori judgments in geometry, I. Kant explained the knowledge of axioms using the word "intuitive". And it becomes unclear whether it is about the empirical or analytic nature of this knowledge, since it is obvious that intuitive knowledge does not belong to either the former or the latter. However, the deduction of theorems from axioms is based on intuition (spatial). If we consider Riemannian geometry, most of the conclusions about geometry made by I. Kant will again be unconfirmed. However, it is clear that similar studies appeared later, and the mathematical method of I. Kant, as proved by J. Hintikka ${ }^{26}$, derived from Euclidean geometry. Therefore, when German thinker explained how concepts are being constructed, he used Euclid's method of proof as an example and extrapolated the results of geometrical researches into the sphere of philosophical analysis of conditions of reason. The philosophy of I. Kant remains within the boundaries of theoretical science of his day.

\section{Apologetic reception}

Kantian philosophy began to attract more analytic philosophers' attention after the methods of logical and linguistic analysis were used to study metaphysical problems. One of the first to do so was P. F. Strawson, the author of "Individuals. An Essay in Descriptive Metaphysics" (1959). It was important for him to demonstrate that the critique of metaphysics by logical positivists (especially R. Carnap and A. J. Ayer) was unfounded. The fact is that there are two types of metaphysics - descriptive and revisionary. The difference between them is that: "descriptive metaphysics is content to describe the actual structure of our thought about the world, revisionary metaphysics is concerned to produce a better structure"27. The scientific principles of philosophy are violated in revisionary metaphysics because it is the result of the intellectual speculation of its authors, in particular R. Descartes, G. Leibniz and G. Berkeley. This metaphysics has no empirical reference in the natural language and cannot claim independent status. There is certainly a grain of truth in their reflections. According to P. F. Strawson, "revisionary metaphysics is at the service of descriptive metaphysics" 28 . The main representatives of descriptive metaphysics were Aristotle and I. Kant. Another prominent thinker, D. Hume, because of his ironic position in philosophy, could be placed to one camp or another.

\footnotetext{
${ }^{26}$ Hintikka J. Kant on the Mathematical Method. The Monist. 1967. Vol. 51. P. 352-375.

27 Strawson P. Individuals: An Essay in Descriptive Metaphysics. London: Routledge, 1990. P. 9.

${ }^{28}$ Ibid. P. 9.
} 
Descriptive metaphysics does not discover new truths, but rethinks what has already been gained. Moreover, it uses a new methodology and puts them into the context of contemporary theoretical and philosophical studies. This process could be compared with the scientific explication of natural phenomena that have long attracted people's attention, but due to the limited knowledge of the outside world, they came up with explanations that were only formally related to unknown phenomena. Similarly, analytic thinker in order to explain traditional philosophical questions such as the problem of truth, reference, objective reality, understanding, sense and meaning, etc., uses new terminology, pays special attention to the linguistic means of expressing our knowledge and interprets the ideas of previous thinkers only from the standpoint of contemporary issues. Following I. Kant, P. F. Strawson intended to reveal the most general conditions of knowledge of such individual objects, or individuals as particulars (material things, historical occurrences, people), which are opposed to universals (qualities, properties, numbers, species). He is interested how these general conditions affect our perception of material objects, and whether they are simply a feature of our knowledge ${ }^{29}$. In this vein, one of the most pressing questions is the connections between transcendental idealism and empirical realism. The point is that by giving scientific status to metaphysical questions (searching for these the most fundamental conditions), one must also prove that they not only form an imaginary world that has nothing to do with the actual one, but can have a connection with empirical reality. It is necessary to show how the knowledge of the metaphysical structures, which are the deep structures of the ordinary language, determine the peculiarities of its functioning and make statements about particulars possible within the spatio-temporal configurations of direct experience. Therefore, to cognize the nature of general objects, one must not only analyze them, but also go to the synthesis of the essential features of individual material objects in the form of universals.

In addition, the question arises of the correspondence of knowledge to reality as a given in itself or at least constituted in the process of cognition and determined by a priori forms of sensuality and categories of understanding. It is not clear how these two worlds relate to each other - the nominal (the reality itself) and the phenomenal (the reality we perceive). The world reflected in the senses is a special and not identical to noumenal world. We do not know why this world is what it is and not different one. For us, the forms of sensuality and the structures of understanding are something that we have to take as a given. They influence the way we shape our experience and determine its specificity. It is likely that if these forms and structures were

\footnotetext{
${ }^{29}$ Ibid. P. 62.
} 
different, our experience would be different. P. F. Strawson, as analytic thinker, became interested in the boundaries of human knowledge. He realized that we could think of many things and such considerations would seem grammatically correct. However, it should be understood that our experience is limited in its expressive means. That is why, in the book "The Bounds of Sense" (1966), which focuses on the study of I. Kant's "Critics of Pure Reason", P. F. Strawson stated: "It is possible to imagine kinds of world very different from the world as we know it. It is possible to describe types of experience very different from the experience we actually have. But not any purported and grammatically permissible description of a possible kind of experience would be a truly intelligible description. There are limits to what we can conceive of, or make intelligible to ourselves, as a possible general structure of experience. The investigation of these limits, the investigation of the set of ideas which forms the limiting framework of all our thought about the world and experience of the world, is, evidently, an important and interesting philosophical undertaking. No philosopher has made a more strenuous attempt on it than Kant" ${ }^{, 30}$.

P. F. Strawson made it clear that the boundaries of our knowledge are defined at the level of metaphysics of experience by such interconnected forms of intuition as space and time, which affect our conceptions of objectivity, unity, causality, representation. These concepts function in language as certain abstractions that cannot simply be deduced from empirical propositions. We must also investigate the nature of philosophical analysis of thought expressed in language. The thoughts we express in language also need to be conceptually analyzed. Based on the analysis of the language, we come to the being of individual objects in space-time. These objects function as subjects, to which different material predicates (M-predicates) are ascribing in the judgment. Interestingly, a person is a special kind of object, which we can also ascribe P-predicates to, for instance beliefs or feelings.

It can be argued that P. F. Strawson developed the ideas of I. Kant and substantially supplemented them with the considerations of contemporary analytic philosophers. He replaced the Kantian distinction of the noumenal and phenomenal world with the distinction of conceptual scheme and empirical content. He was not only interested in what one can know, but what language means we have to express what one can know. P. F. Strawson's conclusions about the interrelation of metaphysics and epistemology are not unambiguous, since the attempt to express Kantian objectivism separately from transcendentalism also requires procedures for verifying the knowledge

${ }^{30}$ Strawson P. The Bounds of Sense: An Essay on Kant's Critique of Pure Reason. London: Routledge, 1975. P. 15. 
gained. In spite of this, his philosophical investigations, in which a special place is occupied with the study of I. Kant's ideas, caused a peculiar metaphysical turn in analytic philosophy. Even today, these topics, which in the heyday of logical empiricism, have been avoided, occupy a prominent place in analytic philosophy.

The metaphysical foundations of epistemology were also investigated by W. Sellars, who combined the linguo-philosophical approach with the transcendental epistemology of I. Kant. In this way, the American thinker intended to bridge the gap between empiricism and rationalism, which was justified in logical positivism. It is no coincidence that W. Sellars became interested in the Kantian theory of experience, in which nature and its forms space and time - are interpreted as a system of representations. In order to understand what empirical is, according to I. Kant, it is important to analyze the content of empirical judgment. W. Sellars also emphasized this and said: "The central theme of the Analytic is that unless one is clear about what it is to judge, one is doomed to remain in the labyrinth of traditional metaphysics" ${ }^{\prime 31}$. Explaining the nature of judgment makes it possible to go beyond metaphysics. W. Sellars, as an analytic philosopher, combined judging and state of affairs, truth and actuality into pairs. This demonstrates the similarity between these concepts, the possibility of their deeper analysis. We can also find a special type of connection between the concepts of empirical knowledge and truth, as well as empirical knowledge and actuality. It is no accident. Moreover, as W. Sellars noted, "the core of Kant's "epistemological turn" is the claim that the distinction between epistemic and ontological categories is an illusion"32. Ontological categories are epistemic. Transcendental logic explains how our reason cognizes the world. Since the reason is part of this world, it influences the process of perception of external objects. The properties of these objects are expressed in certain spatiotemporal predicates. Importantly, these predicates, when they are expressed from a logico-linguistic standpoint of view, "are essential not only to object-language statements, but to the metalinguistic statements that ascribe logical (epistemic) powers to linguistic forms" ${ }^{\prime 3}$. At the level of such metalinguistic concepts as meaning, truth and cognition, epistemology turns into transcendental linguistics, which studies the general properties and patterns of historical languages. Transcendental linguistics allows us to combine our knowledge of empirical facts with more abstract judgments. This linguistics is a metatheoretical construction that is clearly lacking in I. Kant's philosophy.

${ }^{31}$ Sellars W. Some Remarks on Kant's Theory of Experience. The Journal of Philosophy. 1967. Vol. 64, No. 20. P. 634.

${ }^{32}$ Ibid. P. 634.

${ }^{33}$ Ibid. P. 642. 
However, a more conceptual analysis of W. Sellars showed that adequate knowledge of the reference is impossible. In "Empiricism and the Philosophy of Mind"34 (1956), he developed the metaphor of "The Myth of the Given" to confirm the idea of the mismatch of our perceptions to the outside world. It was important for him to prove that to be like something does not mean to be something. And this is just about the level of feelings. At the language level, words are not similar to their referents at all. Such considerations fit perfectly into the Kantian strategy of distinguishing between "noumenon" and "phenomenon". However, W. Sellars also added logico-linguistic analysis to the epistemological one.

In this connection, the ideas of I. Kant were given a new direction of development in analytic philosophy - they were substantially supplemented and interpreted in new theoretical and methodological fields. Such a keen interest of analytic thinkers in the philosophy of I. Kant, on the one hand, and their attempts to critically analyze epistemological issues, on the other one, even gave R. Rorty reason to identify among them causal relationships and claim that: "Analytic" philosophy is one more variant of Kantian philosophy, a variant marked principally by thinking of representation as linguistic rather than mental, and of philosophy of language rather than "transcendental critique", or psychology, as the discipline which exhibits the "foundations of knowledge" ${ }^{35}$. However, such an interpretation of analytic philosophy seems somewhat exaggerated and provocative, since to a large extent the ideas of I. Kant's transcendentalism went against analytic thinkers' empirical studies. They were more interested in his method of critique as a kind of analysis aimed at clarifying thoughts than in attempting to speculatively construct transcendental preconditions for thinking.

\section{CONCLUSIONS}

Analytic philosophers, as it was demonstrated above, have developed Kantian themes of division into noumenon and phenomenon (in the context of the problem of the limits of cognition), the questions of spacetime dimensions of our perception, the thesis of the practical significance of metaphysics, the interpretation of analysis and the doctrine of judgment, in particular analytic and synthetic ones. The method of critique that Kant interpreted as analytic was rethought - and this analytic became a critique in analytic philosophy. At first, this analytic concerned the

${ }^{34}$ Sellars W. Empiricism and the Philosophy of Mind. Minnesota Studies in the Philosophy of Science. Vol. 1 / H. Feigl, M. Scriven (eds.). Minneapolis: University of Minnesota Press, 1956. P. 253-329.

${ }^{35}$ Rorty R. Philosophy and the Mirror of Nature. Princeton: Princeton University Press, 1979. P. 8. 
critique of language and its expressive means, but later, when the need to explore also the preconditions of language arose, it increasingly began to be focused on topics of mind as well as artificial intelligence. Therefore, in order that research is not to be unproven and contradictory, the analytic philosophers first turned to the achievements of the natural sciences. When there was a need to comprehend metaphysical, logicoepistemological or methodological issues, the original and innovative ideas of I. Kant were, of course, advisable to take into account. At the same time the progress in logic, linguistics and the latest research in philosophy certainly should not have been neglected.

\section{SUMMARY}

The article attempts to give a thoughtful assessment of I. Kant's logicoepistemological ideas in the context of the development of analytic philosophy. In this connection, the peculiarities of Kantian interpretation of such ideas as analytic (general and transcendental), analysis, distinction between analytic and synthetic judgments, and the general concept of language were analyzed, and the reception (critical or apologetic) of these ideas was explained. It is substantiated that critical reflection is present in L. Wittgenstein and A. Pap. The former, developing the foundations of his own philosophical concept, repeatedly appealed to the methods proposed by I. Kant to solve logical and epistemological problems, expressed his ideas in modern philosophical language and pointed to different approaches in their interpretation; and the latter, investigating the necessary truths as the basis for epistemology, analyzed the philosophical views of the German thinker and found in them ambiguity and uncertainty. The apologetic reception of I. Kant's views, for its part, is represented by the ideas of P. F. Strawson, who developed them within the conception of descriptive metaphysics, and W. Sellars, who supplemented his epistemological considerations with the ideas of transcendental linguistics. The study showed that in any case, I. Kant's philosophy was significantly enriched and had a true influence on the development of analytic philosophy.

\section{REFERENCES}

1. Козловський В. Стросон і Кант: дескриптивна метафізика як концептуальна передумова аналізу “Критики чистого розуму”. Sentenciae. 2016. № 1 (XXXIV). C. 25-41.

2. Синиця А.С. Аналітична філософія. Львів: ЛДУФК, 2013. 304 с.

3. Циба В. Кантове поняття правила і проблема мови. Філософська думка. 2015. № 2. С. 50-66. 
4. Циба В. Концептуальність споглядання: Селарс добудовує Кантову епістемологію. Sentenciae. 2016. № 1 (XXXIV). C. 42-60.

5. Beaney M. Chronology of Analytic Philosophy and Its Historiography. The Oxford Handbook of The History of Analytic Philosophy / M. Beaney (ed.). Oxford: Oxford University Press, 2015. P. 141-226.

6. Critchley S. Continental Philosophy: A Very Short Introduction. Oxford: Oxford University Press, 2001. XI, 149 p.

7. Hanna R. Kant and the foundations of analytic philosophy. Oxford: Clarendon, 2006. XV, $312 \mathrm{p}$.

8. Hintikka J. Kant on the Mathematical Method. The Monist. 1967. Vol. 51. P. 352-375.

9. Immanuel Kants Logik, ein Handbuch zu Vorlesungen / G.B. Jäsche (her.). Königsberg: Friedrich Nicolovius, 1800. XXIV, $232 \mathrm{s.}$

10. Kant I. Anthropologie in pragmatischer Hinsicht. Leipzig: Verlag von Felix Meiner, 1912. XXII, $328 \mathrm{~s}$.

11. Kant I. Critique of Pure Reason / trans. by: P. Guyer, A.W. Wood. New York: Cambridge University Press, 1998. XI, 785 p.

12. Klaassen T. Wittgenstein as a Kantian Philosopher / 2015. URL: https://philpapers.org/archive/KLAWAA.pdf.

13. Pap A. Semantics and Necessary Truth: An Inquiry Into the Foundations of Analytic Philosophy. New Haven: Yale University Press, 1958. XX, $456 \mathrm{p}$.

14. Reed D. The Origins of Analytic Philosophy: Kant and Frege. London; New York: Continuum, 2010. X, 203 p.

15. Rorty R. Philosophy and the Mirror of Nature. Princeton: Princeton University Press, 1979. XV, 401 p.

16. Sellars W. Empiricism and the Philosophy of Mind. Minnesota Studies in the Philosophy of Science. Vol. 1 / H. Feigl, M. Scriven (eds.). Minneapolis: University of Minnesota Press, 1956. P. 253-329.

17. Sellars W. Some Remarks on Kant's Theory of Experience. The Journal of Philosophy. 1967. Vol. 64, No. 20. P. 633-647.

18. Strawson P. Individuals: An Essay in Descriptive Metaphysics. London: Routledge, 1990. 255 p.

19. Strawson P. The Bounds of Sense: An Essay on Kant's Critique of Pure Reason. London: Routledge, 1975. 296 p.

20. Tarski A. The Concept of Truth in Formalized Languages / trans. by J.H. Woodger. In: Tarski A. Logic, Semantics and Metamathematics. Oxford: Oxford University Press, 1956. P. 152-278.

21. Wittgenstein L. Culture and Value / trans. by P. Winch. Chicago: The University of Chicago Press, 2006. 94 p. 
22. Wittgenstein L. Tractatus Logico-Philosophicus / trans. by C.K. Ogden. London: Kegan Paul, Trench, Trubner \& Co., 1922. XX, 189 p.

23. Wittgenstein L. Philosophical Remarks. Chicago: The University of Chicago Press, 1980. 357 p.

Information about the author:

Synytsia A. S.,

Doctor of Philosophy, Professor at the Department of History of Philosophy, Ivan Franko National University of Lviv 1, Universytetska str., Lviv, 79000, Ukraine 